\title{
Note
}

\section{The Law of Nations and the Offenses Clause of the Constitution: A Defense of Federalism}

\author{
Michael T. Morley
}

One of the most important features of the United States government as originally conceived by the Framers is that, even before the addition of the Bill of Rights, its powers were strictly regulated by the Constitution. ${ }^{1}$ Instead of being a supreme parliament, ${ }^{2}$ able to do whatever it believed necessary to promote the nation's health, safety, welfare, or morals, ${ }^{3}$ Congress was crafted as a legislature of strictly enumerated powers. ${ }^{4}$ Every

1. See Marbury v. Madison, 5 U.S. (1 Cranch) 137, 176 (1803) ("The powers of the legislature are defined, and limited; and that those limits may not be mistaken, or forgotten, the constitution is written."); see also Hawaii v. Mankichi, 190 U.S. 197, 240-41 (1903) (Harlan, J., dissenting) (noting that the Constitution is "full of restrictions upon Congress, and designed to limit the separate departments of Government to the exercise of only expressly enumerated powers and such other powers as may be implied therefrom").

2. On parliamentary power, see Brett W. King, Deconstructing Gordon and Contingent Legislative Authority: The Constitutionality of Supermajority Rules, 6 U. CHI. L. SCH. ROUNDTABLE 133, 189 n.248 (1999) ("[N]o one made the English crown or the English parliament, and no powers have been conferred upon them; for that reason they are unlimited." (quoting A.F. Pollard, THE EVolution OF PARLIAMENT 216 (1926))).

3. Such authority, referred to as the "police power," is constitutionally denied to Congress and reserved to the states. See United States v. Lopez, 514 U.S. 549, 566 (1995) ("The Constitution... withhold[s] from Congress a plenary police power that would authorize enactment of every type of legislation.").

4. See U.S. CONST. art. $1, \S 8$ (enumerating the powers of Congress). 
law passed by Congress must fall within one of these discrete powers, ${ }^{5}$ or be "necessary and proper" to the execution of such a power. ${ }^{6}$

In the decades after the New Deal, however, it seemed as if almost nothing was beyond the purview of the federal government. Nearly any federal law could be upheld as an exercise of the commerce power; ${ }^{7}$ whatever civil rights measures fell outside its scope were justified by Section 5 of the Fourteenth Amendment. ${ }^{8}$ Indeed, in over fifty years, the Supreme Court struck down only one federal law as exceeding Congress's ostensibly limited constitutional authority. ${ }^{9}$

This changed, of course, with three cases starting in the mid-1990s: United States v. Lopez, ${ }^{10}$ City of Boerne v. Flores, ${ }^{11}$ and United States $v$. Morrison. ${ }^{12}$ For the first time in twenty-five years, the Supreme Court actually struck down laws as exceeding Congress's commerce and Reconstruction powers. The Court even set forth guidelines for determining whether statutes are authorized by the Commerce Clause..$^{13}$ As a result of this constitutional upheaval, many academics began to scour the

5. See Printz v. United States, 521 U.S. 898, 919 (1997) (referring to the "Constitution's conferral upon Congress of not all governmental powers, but only discrete, enumerated ones").

6. See U.S. CONST. art. I, $\S 8$, cl. 18 ("The Congress shall have Power ... To make all Laws which shall be necessary and proper for carrying into Execution the foregoing Powers, and all other Powers vested by this Constitution in the Government of the United States ....").

7. See Joseph D. Grano, Teaching the Commerce Clause, 78 B.U. L. REV. 1163,1165 (1998) ("The first thing that is obvious is that the Court's pre-Lopez doctrine permitting Congress carte blanche under the Commerce Clause is inconsistent with the specific enumeration of Congressional powers in Article I and elsewhere in the Constitution.").

8. Section 1 of the Fourteenth Amendment provides:

No State shall make or enforce any law which shall abridge the privileges or immunities of citizens of the United States; nor shall any State deprive any person of life, liberty, or property, without due process of law; nor deny to any person within its jurisdiction the equal protection of the laws.

U.S. CONST. amend. XIV, § 1 . Section 5 of the Amendment states, "Congress shall have power to enforce, by appropriate legislation, the provisions of this article." Id. $\S 5$.

9. See Oregon v. Mitchell, 400 U.S. 112 (1970) (striking down the provisions of the Voting Rights Act Amendments of 1970 that extended the franchise to eighteen-year-olds in state elections, on the grounds that these provisions exceeded Congress's powers under Section 5 of the Fourteenth Amendment).

10. 514 U.S. 549 (1995) (holding that the Gun-Free School Zones Act exceeded Congress's power under the Commerce Clause).

11. 521 U.S. 507 (1997) (holding that the Religious Freedom Restoration Act exceeded Congress's power under Section 5 of the Fourteenth Amendment).

12. 529 U.S. $598(2000)$ (holding that provisions of the Violence Against Women Act providing federal civil remedies for rape victims exceeded Congress's powers under both the Commerce Clause and Section 5 of the Fourteenth Amendment).

13. On this point, the Court stated:

First, Congress may regulate the use of the channels of interstate commerce....

Second, Congress is empowered to regulate and protect the instrumentalities of interstate commerce, or persons or things in interstate commerce.... Finally, Congress' commerce authority includes the power to regulate those activities having a substantial relation to interstate commerce....

Lopez, 514 U.S. at 558-59. 
Constitution, looking for alternate fonts of congressional authority to replace the now truncated commerce and Reconstruction powers.

Perhaps the most ingenious suggestion is that proposed by Professor Beth Stephens. ${ }^{14}$ Building upon an amicus brief filed in Morrison by certain "International Law Scholars and Human Rights Experts," 15 she argues that a little-known constitutional provision, the Offenses Clause, could serve to authorize not only the laws struck down in Lopez, Boerne, and Morrison, but also legislation affecting almost all spheres of domestic activity. The Clause empowers Congress to "define and punish ... Offences against the Law of Nations." ${ }^{16}$ Professor Stephens claims that this provision empowers Congress to enact civil and criminal legislation in any area upon which international law touches. Given the broad sweep of contemporary international law, this approach would turn the Offenses Clause into a Commerce Clause for the twenty-first century. It would bring virtually every aspect of society, including those traditionally left to state regulation, under congressional authority. ${ }^{17}$

This Note takes the opposite point of view, ${ }^{18}$ arguing that the Offenses Clause is a modest grant of authority, insufficient to support laws such as

14. Beth Stephens, Federalism and Foreign Affairs: Congress's Power To "Define and Punish . . Offenses Against the Law of Nations," 42 WM. \& MARY L. REV. 447 (2000). Although similar arguments have occasionally been made based on the Treaty Clause and the Necessary and Proper Clause, see infra note 21 , the only other law review article which has recommended this expansive new interpretation of the Offenses Clause is Michael H. Posner \& Peter J. Spiro, Adding Teeth to United States Ratification of the Covenant on Civil and Political Rights: The International Human Rights Conformity Act of 1993, 42 DEPAUL L. REV. 1209, 1223-26 (1993). The Posner and Spiro piece dedicates only a few pages to a cursory overview of this topic, however.

15. See Brief Amici Curiae on Behalf of International Law Scholars and Human Rights Experts in Support of Petitioners, United States v. Morrison, 529 U.S. 598 (2000) (Nos. 99-5, 9929), 1999 WL 1037253 [hereinafter International Law Scholars Brief] (arguing, in part, that the provisions of the Violence Against Women Act at issue were constitutionally authorized by the Offenses Clause). None of the Justices even acknowledged this argument.

16. U.S. CONST. art. I, $\S 8, \mathrm{cl}$. 10. The full constitutional provision in which the Offenses Clause is found states that Congress shall have power "[t]o define and punish Piracies and Felonies committed on the high Seas, and Offences against the Law of Nations." Id.

17. See Stephens, supra note 14, at 449 ("Properly understood, the Offenses Clause grants Congress exceptional powers to incorporate international law into federal law, even when such norms infringe upon areas otherwise regulated by the states.").

18. To date, no one has challenged Professor Stephens's position. Prior to her piece, there were three major works dealing with the Offenses Clause. Charles D. Siegal, Deference and Its Dangers: Congress' Power To "Define ... Offenses Against the Law of Nations," 21 VAND. J. TRANSNAT'L L. 865 (1988) (assessing the legitimacy, under the Offenses Clause, of statutes banning picketing in the vicinity of embassies); Howard S. Fredman, Comment, The Offenses Clause: Congress' International Penal Power, 8 ColuM. J. TRANSNAT'L L. 279, 308 (1969) (arguing that the purpose of the Offenses Clause "is to enable Congress to vindicate the interests of all nations in sane and amicable relations by punishing individuals who are intent upon acts which might cause serious disturbances of international order"); Zephyr Rain Teachout, Note, Defining and Punishing Abroad: Constitutional Limits on the Exiraterritorial Reach of the Offenses Clause, 48 DUKE L.J. 1305 (1999) (arguing that international law principles governing extraterritorial jurisdiction apply to prosecutions under the Offenses Clause). All of these pieces 
the Gun-Free School Zones Act ${ }^{19}$ and the Violence Against Women Act (VAWA), ${ }^{20}$ or to undermine American federalism. The Clause affirms, rather than undermines, the balance of state-federal relations that the Framers intended. ${ }^{21} \mathrm{I}$ argue that it allows for the enactment of legislation touching upon only that fixed, discrete set of areas involving intercourse with foreign nations and their citizens-including navigation, trade, war, and diplomacy-that comprise what the Framers believed to be the immutable law of nations. ${ }^{22}$

accept the premise, without significant discussion, that the Clause empowers Congress to enact only criminal, rather than civil, penalties.

I agree with Professor Stephens that the Clause permits both civil and criminal sanctions. See Stephens, supra note 14, at 454 ("A close examination of the text of the Offenses Clause, the historical context in which it was drafted, and the constitutional structure of which it is a key part, demonstrates that the Clause was not-and should not be-limited to criminal prosecutions."). The Supreme Court has recognized that civil penalties, although frequently intended to be compensatory, can also serve as punishments. Browning-Ferris Indus., Inc. v. Kelco Disposal, Inc., 492 U.S. 257, 274 n.20 (1989) ("Damages are designed not only as a satisfaction to the injured person, but likewise as a punishment to the guilty, to deter from any such proceeding for the future ..." (quoting Wilkes v. Wood, 98 Eng. Rep. 489, 498-99 (K.B. 1763))). Moreover, punitive damages - a type of civil remedy-are by definition intended to punish. See Gertz v. Robert Welch, Inc., 418 U.S. 323, 350 (1974) ("Punitive damages are not compensation for injury. Instead, they are private fines levied by civil juries to punish reprehensible conduct and to deter its future occurrence.").

19. Gun-Free School Zones Act of 1990, 18 U.S.C. § 922(q)(2)(A) (1994).

20. Violence Against Women Act, 42 U.S.C. $\S 13,981$ (2000). As noted above, certain provisions of this Act were struck down in United States v. Morrison, 529 U.S. 598 (2000).

21. One might wonder why this discussion is necessary given the orthodox view that the Treaty Clause empowers Congress to pass legislation necessary for the domestic implementation of treaties. See, e.g., Gavin R. Villareal, Note, One Leg To Stand on: The Treaty Power and Congressional Authority for the Endangered Species Act After United States v. Lopez, 76 TEX. L. REV. 1125, 1153 (1998) ("Congress is empowered to enact legislation that is "necessary and proper' for the implementation of the goals of approved treaties.").

There are several reasons why an independent examination of the Offenses Clause is worthwhile. First, the discussion has already been initiated by Professor Stephens's article and the International Law Scholars Brief. Second, the scope of the treaty power has come under strong attack; many scholars have come to doubt whether it empowers Congress to pass legislation that could not be enacted under its substantive Article I, Section 8 powers. See Curtis A. Bradley, Breard, Our Dualist Constitution, and the Internationalist Conception, 51 STAN. L. REV. 529, 553 (1999) (expressing doubt that the treaty power trumps federalism); David M. Golove, TreatyMaking and the Nation: The Historical Foundations of the Nationalist Conception of the Treaty Power, $98 \mathrm{MICH}$. L. REV. 1075, 1085 (2000) ("[T]reaties are not immune from federalism limitations ...."). Third, because "consistent interpretations of similar constitutional concepts reinforce each other," an expansive view of the Offenses Clause can lend additional legitimacy to a similar view of the treaty power. E-mail from Beth Stephens, Professor of Law, Rutgers Law School at Camden, to Michael T. Morley (Apr. 2, 2002) (on file with author). Fourth, Professor Stephens argues that congressional power under the Offenses Clause is greater than that granted by the Treaty Clause because it allows for the enactment of domestic legislation concerning not only the wide range of areas covered by treaties, but matters governed by international customary norms as well. See Stephens, supra note 14, at 452 . Finally, "[a]cademic honesty, as well as the fact that Congress may base legislation solely upon the Offenses Clause, compels this examination." Teachout, supra note 18, at 1307.

22. See infra Part II. 
Part I of this Note explores the claims made by Professor Stephens and the International Law Scholars, setting forth their case for viewing the Offenses Clause as an important source of substantive authority for Congress. It also examines the consequences of this approach, outlining the wide range of areas traditionally reserved to the states that it would enable Congress to regulate. Part II refutes the primary assumption upon which this interpretation is based. First, I argue that the phrase "law of nations" as used in the Offenses Clause is a term of art that is not synonymous with international law. I demonstrate that it refers to principles in certain welldefined areas that govern interactions among foreign countries and foreign nationals. The term excludes wholly domestic conduct that does not have a direct effect on foreign nations or nationals. Because the law of nations is rooted in natural law, its substantive content was understood by the Framers as being immutable. While modern-day treaties and evolving international norms are important parts of international law, they cannot expand the scope of the law of nations.

Part III argues that even if courts abandon the true meaning of the phrase "law of nations" and insist on interpreting it in a modern light, the most faithful modern analogue of this concept is neither international law as a whole, nor customary international law, but jus cogens norms. Allowing for the enforcement of jus cogens norms under the Offenses Clause is less faithful to the provision's true meaning than the approach advocated in Part II. The concept of jus cogens, however, has many important similarities to the law of nations, and the range of recognized jus cogens norms is fairly narrow. Consequently, this interpretation of the Offenses Clause would be a legitimate compromise, retaining much of the Clause's original meaning while preventing it from being used to eliminate the boundary between state and federal authority. Part IV concludes.

The Offenses Clause has been virtually ignored throughout most of this nation's history and has yet to be thoroughly explored by the legal literature. ${ }^{23}$ In light of suggestions that Congress use the Clause as a replacement for its once-omnipotent commerce and Reconstruction powers, a thorough examination of the history and meaning of its central phrase "the law of nations"-is necessary.

23. The Offenses Clause is hardly ever mentioned, and the few references to it that do exist are often brief and inconclusive. See, e.g., Peter J. Spiro, Foreign Relations Federalism, 70 U. COLO. L. REv. 1223, 1273 n.185 (1999) ("The Offenses Clause also stands as an intriguing, if obscure, possible source of affirnative federal power in the area."); see also Posner \& Spiro, supra note 14 (offering a brief discussion of the Offenses Clause). But see supra note 18 (listing the three articles that treat the Offenses Clause in depth). 


\section{THE ARGUMENT FOR A BROAD INTERPRETATION OF THE OFFENSES CLAUSE}

The argument for an expansive reading of the Offenses Clause is straightforward, but rests on critical assumptions about the meaning of the phrase "law of nations." Professor Stephens readily admits that she assumes "'the terms the law of nations and international law are used interchangeably." 24 Because the term "international law" includes international agreements and customary international norms, Stephens concludes that the phrase "law of nations" does, as well. ${ }^{25}$ If one accepts Stephens's premise, then an international agreement or international norm addressing a particular topic or calling for state action in a certain area may serve as the basis for federal legislation in that area under the Offenses Clause. Treaties and international law norms may thereby enable the enactment of legislation that Congress would be otherwise powerless to pass.

This theory has significant ramifications for recent Supreme Court decisions enforcing limits on the federal government's power. Under wellestablished Supreme Court precedent, a statute can be justified as an application of congressional power under the Offenses Clause even if Congress did not state that it was exercising that power at the time of the law's enactment. ${ }^{26}$ Thus, statutes such as the Violence Against Women Act struck down in Morrison ${ }^{27}$ could be upheld under an expansive interpretation of this font of authority.

The Declaration on the Elimination of Violence Against Women, for instance, declares that nations should "[e]xercise due diligence to prevent, investigate and, in accordance with national legislation, punish acts of

24. Stephens, supra note 14 , at 449 (quoting MARK W. JANIS, AN INTRODUCTION To INTERNATIONAL LAW 1 (1988)). The Restatement (Third) of Foreign Relations supports this interpretation. RESTATEMENT (THIRD) OF THE FOREIGN RELATIONS LAW OF THE UNITED STATES 41 (1990) (Introductory Note to Chapter 2) [hereinafter RESTATEMENT] ("[T] he law of nations, [was] later referred to as international law.").

25. The International Law Scholars, in contrast, claim only that the phrase "embraces customary international law." International Law Scholars Brief, supra note 15, at *18. Jack Goldsmith has interpreted the phrase in the same way. See Jack L. Goldsmith, Federal Courts, Foreign Affairs, and Federalism, 83 VA. L. REV. 1617, 1639 n.100 (1997) ("The Constitution's only mention of customary international law is in [the Offenses Clause]."); see also Teachout, supra note 18 , at 1307 (interpreting the phrase in the same way).

26. In United States v. Arjona, 120 U.S. 479 (1887), the Supreme Court ruled that a federal statute prohibiting the counterfeiting of foreign currencies was constitutional under the Offenses Clause. The Court stated that the law "define[d] an offence against the law of nations as clearly as if Congress had in express terms so declared." Id. at 488 . The Court went on to note that "it has never been supposed" that statutes enacted under the Offenses Clause "were invalid because they did not expressly declare that the offences there defined were offences against the law of nations." Id.

27. United States v. Morrison, 529 U.S. 598 (2000). 
violence against women, whether those acts are perpetrated by the State or by private persons. ${ }^{28}$ Furthermore, nations should

[d]evelop penal, civil, labour and administrative sanctions in domestic legislation to punish and redress the wrongs caused to women who are subject to violence; women who are subjected to violence should be provided with access to the mechanisms of justice and, as provided for by national legislation, to just and effective remedies for the harm that they have suffered. ${ }^{29}$

The term "violence" is explicitly defined to include rape. ${ }^{30}$

This document complements the Convention on the Elimination of All Forms of Discrimination Against Women, which obligates nations to

take all appropriate measures ... [to] modify the social and cultural patterns of conduct of men and women, with a view to achieving the elimination of prejudices and customary and all other practices which are based on the idea of the inferiority or the superiority of either of the sexes or on stereotyped roles for men and women. ${ }^{31}$

Both the Declaration and the Convention more clearly spell out nations' obligations under the International Covenant on Civil and Political Rights (ICCPR). ${ }^{32}$ The ICCPR requires each nation to "respect and to ensure to all individuals within its territory... the rights recognized in the present Covenant, without distinction of any kind, such as ... sex.."33 Among the rights recognized by the ICCPR are those of "life . . liberty, and security of person." ${ }^{34}$ It is difficult to imagine any act more violative of the security of a person than rape. These instruments, when read together, clearly make

28. Declaration on the Elimination of Violence Against Women, G.A. Res. 104, U.N. GAOR, 48th Sess., Agenda Item 111 , at 4, U.N. Doc. A/RES/48/104 (1994).

29. Id. at 5.

30. Id. at 3.

31. Convention on the Elimination of All Forms of Discrimination Against Women, G.A. Res. 180, U.N. GAOR, 34th Sess., Annex, Agenda Item 75, at 4, U.N. Doc. AJRES/34/180 (1980). The United States has signed but not ratified this convention. See UNITED NATIONS, MULTILATERAL TREATIES DEPOSITED WITH THE SECRETARY-GENERAL: STATUS AS AT 31 DECEMBER 2000, at 228-29 (2001) [hereinafter MULTILATERAL TREATIES].

32. International Covenant on Civil and Political Rights, adopted Dec. 19, 1966, S. ExEC. DoC. E, 95-2, at 23 (1978), 999 U.N.T.S. 171 (entered into force Mar. 23, 1976) [hereinafter ICCPR]. The United States signed and ratified the ICCPR with certain understandings and declarations. See U.S. DEP'T OF STATE, TREATIES IN FORCE 397-98 (2001).

33. ICCPR, supra note 32, art. 2, § 1, S. ExEC. DOC. E, 95-2, at 24, 999 U.N.T.S. at 173.

34. Id. art. 6, § 1, S. EXEC. DOC. E, 95-2, at 25, 999 U.N.T.S. at 174; id. art. 9, § 1, S. EXEC. DoC. E, 95-2, at 26, 999 U.N.T.S. at 175; see also International Law Scholars Brief, supra note 15 , at $* 7$ ("Under the Covenant, gender-based violence is an extreme form of gender based discrimination which also violates a broad range of other fundamental rights. . . The ICCPR requires a State Party to respect and ensure all rights frec from all forms of discrimination, including distinction on the basis of sex ...."). 
violence against women in general, and rape in particular, a violation of international law. Professor Stephens and the International Law Scholars maintain that such violations of international law $^{35}$ are by definition offenses against the law of nations, for which the Offenses Clause empowers the government to enact civil and criminal penalties. Under this reasoning, the VAWA would be constitutional. ${ }^{36}$

A similar case can be made with respect to the Religious Freedom Restoration Act (RFRA), portions of which were invalidated in Boerne. ${ }^{37}$ The RFRA required facially neutral federal, state, and local laws that infringed upon religious freedom to pass a statutorily defined strict scrutiny test. ${ }^{38}$ This Act, too, can be seen as a manifestation of Congress's power to define and punish offenses against the law of nations as understood by Professor Stephens. ${ }^{39}$ One international declaration proclaims, "Persons belonging to national or ethnic, religious and linguistic minorities ... have the right to enjoy their own culture, to profess and practise their own religion, and to use their own language, in private and in public, freely and without interference or any form of discrimination." 40 The Universal Declaration of Human Rights buttresses this guarantee, declaring, "Everyone has the right to freedom of thought, conscience and religion; this right includes freedom to change his religion or belief, and freedom, either alone or in community with others and in public or private, to manifest his religion or belief in teaching, practice, worship, and observance.",41

According to Stephens's reasoning, Congress would be justified in assuming that unnecessarily burdening the free exercise of religion is an offense against the law of nations and that the federal government is

35. Professor Stephens argues that treaties are part of the law of nations, while the International Law Scholars maintain that these treaties are evidence of international customary norms protecting women. See supra notes $24-25$ and accompanying text.

36. The International Law Scholars Brief also claims that the VAWA was justified under the treaty power. International Law Scholars Brief, supra note 15, at *3-15; see also supra note 21.

37. City of Boerne v. Flores, 521 U.S. 507 (1997).

38. Religious Freedom Restoration Act of 1993, 42 U.S.C. $\S \S 2000 \mathrm{bb}$ to $2000 \mathrm{bb}-4$ (1994) (repealed in part 2000). According to the Act, "[g]overnment may substantially burden a person's exercise of religion only if it demonstrates that application of the burden to the person ... is in furtherance of a compelling governmental interest... [and] is the least restrictive means of furthering that compelling governmental interest." Id. § $2000 \mathrm{bb}-1$ (b).

39. See Stephens, supra note 14 , at 549-50; cf. Gerald L. Neuman, The Global Dimension of RFRA, 14 CONST. COMMENT. 33, 49-54 (1997) (discussing how the RFRA might be justified under international law).

40. Declaration on the Rights of Persons Belonging to National or Ethnic, Religious and Linguistic Minorities, G.A. Res. 135, U.N. GAOR, 47th Sess., Annex, Agenda Item 97(b), at 4, U.N. Doc. A/RES/47/135 (1992).

41. Universal Declaration on Human Rights, G.A. Res. 217 (III)(A), U.N. GAOR, 3d Sess., at 74, U.N. Doc. A/810 (1948); see also ICCPR, supra note 32, art. 27, S. EXEC. DOC. E, 95-2, at 31,999 U.N.T.S. at 179 ("[P]ersons belonging to [ethnic, religious, or linguistic] minorities shall not be denied the right, in community with the other members of their group, to enjoy their own culture, to profess and practise their own religion, or to use their own language."). 
empowered to stop it. One could similarly claim that the Gun-Free School Zones Act ${ }^{42}$ struck down in Lopez $^{43}$ enforced the law of nations as outlined in multilateral agreements concerning education ${ }^{44}$ and the rights and safety of children. ${ }^{45}$

This argument need not be applied solely to laws struck down in past Supreme Court cases, however. Existing international agreements cover almost every imaginable aspect of society, including marriage,${ }^{46}$ juvenile justice, ${ }^{47}$ and education. ${ }^{48}$ Given this wide range of international agreements, a broad reading of the Offenses Clause ${ }^{49}$ would virtually eliminate any remaining vestiges of federalism from our government. Moreover, if the President and Senate can empower the federal government to legislate in a particular area simply by entering into a treaty concerning that area, then the federal government is ultimately responsible for determining the scope of its own power, a result contrary to the Framers' careful design.

This brings to light a second assumption upon which Professor Stephens bases her claims- that there are no constitutional restrictions upon the substantive content of treaties, aside from those aimed at protecting individual rights. ${ }^{50}$ If federalism-based restrictions on the treaty power do exist, however, then the range of legislation permissible under the

42. Gun-Free School Zones Act of 1990, 18 U.S.C. $\S 922(q)(2)(A)(1994)$.

43. United States v. Lopez, 514 U.S. 549 (1995).

44. Recommendation Concerning Education for International Understanding, Co-operation and Peace and Education Relating to Human Rights and Fundamental Freedoms, U.N. ESCOR, 18th Sess., 36th plen. mtg. at 147, 148 (1974) (outlining several objectives which "should be regarded as major guiding principles of educational policy," and listing some substantive areas that should be incorporated into school curricula); see also Convention on the Rights of the Child, G.A. Res. 25, U.N. GAOR, 44th Sess., Annex, Agenda Item 108, at 170, U.N. Doc. A/RES/44/25 (1989); Convention Against Discrimination in Education, U.N. ESCOR, 11th Sess., 30th plen. mtg. at $119,120(1960)$. The United States signed but did not ratify the Convention on the Rights of the Child. See Multilateral TREatIES, supra note 31, at 274-75.

45. See generally Convention on the Rights of the Child, supra note 44.

46. Convention on Consent to Marriage, Minimum Age for Marriage and Registration of Marriages, G.A. Res. 1763A(xvii), U.N. GAOR, 17th Sess., Supp. No. 17, Annex, at 28, U.N. Doc. A/RES/17/1763 (1962); see also ICCPR, supra note 32, art. 23, S. EXEC. DOC. E, 95-2, at 30, 999 U.N.T.S. at 179.

47. United Nations Guidelines for the Prevention of Juvenile Delinquency, G.A. Res. 112, U.N. GAOR, 45th Sess., Annex, Agenda Item 100, at 200, U.N. Doc. A/RES/45/112 (1990); United Nations Standard Minimum Rules for the Administration of Juvenile Justice, G.A. Res. 33, U.N. GAOR, 40th Sess., 96th plen. mtg., Annex, Agenda Item 98, at 206, U.N. Doc. A/RES/40/33 (1985).

48. See supra note 44.

49. A broad interpretation of the Offenses Clause would also give support to a similarly unrestricted view of the treaty power. See supra note 21.

50. See Reid v. Covert, 354 U.S. 1, 18 (1957) ("To the extent that the United States can validly make treaties, the people and the States have delegated their power to the National Government and the Tenth Amendment is no barrier."); see also Missouri v. Holland, 252 U.S. 416,434 (1920) ("No doubt the great body of private relations usually fall within the control of the state, but a treaty may override its power."). 
Offenses Clause would be drastically curtailed. ${ }^{51}$ Although an examination of the breadth of the treaty power is beyond the scope of this Note, it is helpful to bear this postulate in mind. ${ }^{52}$

Having explored the argument put forth by Professor Stephens and the International Law Scholars for an expansive interpretation of the Offenses Clause, as well as the dramatic consequences to which it could lead, we can now examine why this approach should be rejected.

\section{ThE TRUe MEANING OF THE "LAW OF NATIONS"}

A critical problem with the theories discussed above is that they equate the law of nations with either international law (which include treaties and other international agreements) or customary international law. As a result, they conclude that the substantive content of the law of nations can change over time. Professor Stephens states, for instance, "The framers understood that the law of nations would evolve in ways that they could not control or predict." ${ }^{53}$ I believe that this understanding of the law of nations is erroneous. In this Part, I attempt to demonstrate that the phrase "law of nations," as understood by the Framers and used in the Constitution, is not synonymous with "international law."

Most importantly, the term "law of nations" does not include agreements or norms that address a country's treatment of its own nationals or other purely domestic matters. Instead, the law of nations governs actual interactions between countries, and by extension between their citizens, in discrete areas such as war, trade, navigation, and diplomacy. Moreover, the concept is closely related to natural law ${ }^{54}$ and refers to a body of principles

51. If the government entered into treaties or other international agreements outside the scope of its constitutional authority, those instruments would be as domestically void as a statute that was beyond the government's power to enact. Although other nations would undoubtedly consider such agreements binding, they could not serve as the basis for domestic legislation.

52. Several authors have persuasively argued in favor of such restrictions. See Bradley, supra note 21, at 553 ("At first glance, it might appear that ... purported immunity of the treaty power from federalism restraints has been endorsed by the Supreme Court. . . The Holland decision, however, is far from clear on this point."); Curtis A. Bradley, The Treaty Power and American Federalism, 97 MICH. L. REV. 390, 450 (1998) ("[T] he federal government should not be able to use the treaty power (or executive agreement power) to create domestic law that could not be created by Congress."); Golove, supra note 21, at 1281 ("Were the President and Senate to make a treaty on a subject inappropriate for negotiation and agreement, and thus beyond the scope of the treaty power, the treaty would be invalid under the Tenth Amendment.").

53. Stephens, supra note 14 , at 452.

54. Oppenheim writes, "The modern Law of Nations in particular owes its very existence to the theory of the Law of Nature." 1 L. OPPENHEIM, INTERNATIONAL LAW 89 (H. Lauterpacht ed., 7th ed. 1948); see also WILliam OKE MANNING, COMMENTARIES ON THE LAW OF NATIONS 3 (Shelton Amos ed., Cambridge, MacMillan \& Co. 1875) ("[T]he fundamental principles of the Law of Nations arise from the Law of Nature."). 
understood as being either of divine origin or derivable from reason..$^{55}$ Due to these underpinnings, as explained later in this Part, the law of nations was widely accepted as being immutable; neither treaties nor changing international norms could affect its inherent nature or expand its reach into other areas. Because of the immutable nature of the law of nations, the Offenses Clause, unlike other constitutional provisions, was not expected to evolve with time. ${ }^{56}$

While some scholars who influenced the Framers' generation regarded treaties as part of the law of nations (treaties were sometimes labeled the "voluntary" or "positive" law of nations), they were not understood as capable of expanding the law of nations into new areas. The only treaties these writers discussed dealt with mutual intercourse among nations or foreign nationals in the well-recognized fields discussed above. Moreover, several of the writers discussed below do not even include treaties within the scope of the law of nations.

My examination of the historical record is divided into five Sections. Section II.A briefly explores the linguistic history of the phrase "law of nations," explaining how its roots in the Roman jus gentium distinguish it from "international law." Section II.B examines the works of the preeminent philosophers and scholars who influenced the Framers' beliefs in this area. Section II.C turns to early American court rulings from 17751810 to examine early judicial interpretations of the phrase. Section II.D analyzes the perspectives offered by the Framers and their generation regarding the meaning of this term, focusing in particular on the influence of their beliefs concerning natural law. Finally, Section II.E looks to judicial interpretations of the Offenses Clause over the past 200 years,

55. All of the classic law-of-nations scholars who influenced American thought in this area grounded their "theories firmly in a natural law jurisprudence.... [T] he law of nations was equally affected, and indeed defined, by the larger natural law theories of the age. Universality, immutability, divinity, reason-all hallmarks of the natural law theory-formed indispensable parts of the general theory of the law of nations." Douglas J. Sylvester, International Law as Sword or Shield? Early American Foreign Policy and the Law of Nations, 32 N.Y.U. J. INT'L L. \& POL. 1, 67 (1999).

56. In this respect, the Offenses Clause differs from constitutional provisions such as the First and Eighth Amendments. See U.S. ConST. amend. I "Congress shall make no law ... abridging the freedom of speech ...."); U.S. CONST. amend. VIII (prohibiting the infliction of "cruel and unusual punishments"); Roth v. United States, 354 U.S. 476, 489 (1957) (holding that material is obscene and excluded from First Amendment protection if "to the average person, applying contemporary community standards, the dominant theme of the material taken as a whole applies to prurient interest" (emphasis added)); Weems v. United States, 217 U.S. 349 (1910). On this point, the Weems Court asserted that the Framers, in enacting the Eighth Amendment, "surely . . . intended more than to register a fear of the forms of abuse that went out of practice with the Stuarts ... or to prevent only an exact repetition of history. We cannot think that the possibility of a coercive cruelty being exercised through other forms of punishment was overlooked." Weems, 217 U.S. at 372-73. 
demonstrating how these precedents are consistent with my conception of an immutable and limited law of nations.

\section{A. Linguistic History of the Phrase "Law of Nations"}

The phrase "law of nations" developed from the Roman concept of $j u s$ gentium. ${ }^{57}$ While the jus civile governed relations among Roman citizens, the jus gentium controlled interactions with or among foreigners. ${ }^{58}$ Over time, "the belief gradually prevailed among the Roman lawyers that the old Jus Gentium was in fact the lost code of Nature"s9 - that is, that the jus gentium was a facet of natural law.

This intimate affiliation between the jus gentium and natural law (jus naturale) arose in part from the fact that the jus gentium was thought to be based on universal principles and usages that were "common to all nations... among whom justice was administered by Roman magistrates." ${ }^{, 60}$ These principles were "regarded as so simple and reasonable that it was assumed they must be recognized everywhere and by every one. ${ }^{, 61}$ Put another way, they were somehow dictated by nature, simply waiting to be apprehended by the rational mind. ${ }^{62}$

Later works on the law of nations, in particular those of Grotius, applied the principles of the jus gentium to intercourse among nations and foreign nationals ${ }^{63}$ As a result, the law of nations was steeped in natural law origins, leading to its perception as universal and immutable. Moreover, since the jus gentium pertained only to interactions involving foreigners, it is difficult to see how the law of nations into which it

57. AMOS S. HERSHEY, THE ESSENTIALS OF INTERNATIONAL PUBLIC LAW 2 (1912) (noting that the phrase "law of nations" is a translation of the French "droit des gens," itself "a translation of the Latin jus gentium, - a phrase which bore a very different meaning from that of 'International Law"').

58. THE EARL OF BIRKENHEAD, INTERNATIONAL LAW 6 (Ronw Moelwyn-Hughes ed., 1927) (noting that the rules "[t]o adjust disputes when one of the parties was an alien ... [were] given, by reference to their source, the name jus gentium, or law of nations").

59. SiR HENRY SUMNER MAINe, ANCIENT LAW 46 (Dorset Press 1986) (1861).

60. HERSHEY, supra note 57, at 43; see also GARY L. MARIS, INTERNATIONAL LAW 11 (1984) ("This concept of $j u s$ gentium was instrumental in conceptualizing a family of nations with a law common to all.").

61. J.L. BRIERLY, THE LAW OF NATIONS 10 (1928).

62. GERHARD VON GLAHN, LAW AMONG NATIONS 26 (6th ed. 1992) ("The law of nature, later termed natural low, was believed to have been naturally implanted in men and to comprehend unchangeable and exact justice, universal in scope and self-evident to any individual exercising his 'right reason,' or the moral faculty with which he was endowed.").

63. J.E.S. FAWCETT, THE LAW OF NATIONS 26 (1968) (asserting that over time, "the jus gentium was slowly transformed from a body of special rules into a general law of nations"); HERSHEY, supra note 57, at 58 ("[Grotius] borrowed largely from the Roman jus gentium the leading principles of which had been practically identified with the jus naturale."). 
developed could encompass the wholly domestic relationship between a government and its own citizens.

Whereas the phrase "law of nations" has a long history, the term "international law" is of much more recent origin. In 1650, Richard Zouche distinguished the "Law of Nations" from the "Jus inter Gentes," or the "Law between Nations." ${ }^{64} \mathrm{He}$ defined the "Law of Nations" as "[t]hat which natural reason has established among all men [and] is respected by all alike." ${ }^{, 65}$ It is the law by which "nations are separated, kingdoms founded, [and] commerce instituted." ${ }^{\prime 66}$ In contrast, Zouche explained the "Law between Nations" as "the whole law of Peace and War," similar to the Roman jus feciale. It "decide[s] questions concerning the community between nations both in peace and in war. ${ }^{167}$ While this description of the "Law between Nations" appears to encompass more than the law of nations was traditionally understood as embracing, Zouche's book focuses on traditional questions of diplomacy and warfare. Nonetheless, this work at least introduces the concept of a field of transnational law potentially broader than the traditional law of nations.

Jeremy Bentham is widely credited with having actually coined the phrase "international law" around 1780; it is thought to be rooted in the jus inter gentes. ${ }^{68}$ According to one treatise:

Jus inter gentes was used by Zouche in 1650 to name the real field of international law. Law of nations was the term commonly used in England till the days of Bentham (1748-1832); since that time the term international law, which he adopted, has steadily grown in favor, until it has come into almost universal use in Englishspeaking countries. ${ }^{69}$

In his Introduction to the Principles of Morals and Legislation, Bentham wrote that people may "be considered either as members of the same state, or as members of different states: in the first case, the law [that governs them] may be referred to the head of internal, in the second case, to that of international jurisprudence., ${ }^{, 70} \mathrm{He}$ maintained that international jurisprudence governed "the mutual transactions between sovereigns as

64. Richard Zouche, AN Exposition of Fecial Law and Procedure 1 (James Brown Scott \& Thomas Erskine Holland eds. \& J.L. Brierly trans., Carnegie Inst. of Wash. 1911) (1650).

65. Id.

66. Id

67. Id. at 2.

68. HERSHEY, supra note 57 , at 2 n.2; see also GLAHN, supra note 62, at 26 (crediting Bentham with using the term in 1780).

69. GEORGE GRAFTON WILSON, INTERNATIONAL LAW 8 (George Grafton Wilson \& George Fox Tucker eds., 9th ed. 1935).

70. JeREMY BENTHAM, AN INTRODUCTION to THE PRINCIPLES OF MORALS AND LEGISLATION 326 (Hafner Publ'g Co. 1948) (1789). 
such." Bentham added a footnote to this section, stating that "[t]he word international, it must be acknowledged, is a new one; though, it is hoped, sufficiently analogous and intelligible. It is calculated to express, in a more significant way, the branch of law which goes commonly under the name of the law of nations." 72

Bentham also drafted an essay entitled Principles of International Law, in which he advocated a utilitarian approach to international relations. ${ }^{73} \mathrm{He}$ argued that "[t]he end that a disinterested legislator would propose to himself, would . . . be the greatest happiness of all nations taken together." ${ }^{.74}$ To this end, he concluded that "new international laws [should] be made upon all points which remain unascertained" among nations-especially those points in which their interests "are capable of collision." 75

Bentham does not mention natural law, the jus gentium, or the dictates of "right reason." Instead, he called for the creation of whatever international laws may be necessary to maximize worldwide happiness. Under this formulation, the substance of international law is not limited to particular areas and does not exclude certain types of agreements. Given the baggage associated with the term "law of nations," it is probably no accident that Bentham eschewed it in favor of "international law," a term which has since become ubiquitous.

The distinct origins of the phrases "international law" and "law of nations" bolster the conclusion that they are not interchangeable. Whereas the former has been termed "wonderfully complex," the latter "is easily reducible to a multivolume treatise, now gathering dust in our law libraries." 76

\section{B. Philosophers on the Law of Nations}

In drafting and interpreting the Constitution, both the Framers and Founding-era judges were heavily influenced by certain European scholars who believed the law of nations to be intimately intertwined with natural law. "Grotius, Bynkershoek, Wolff, Vattel, and Pufendorf formed the

71. Id. at 261 .

72. Id. at $260-61$.

73. JEREMY BENTHAM, Principles of International Law, in 2 THE WORKS OF JEREMY BENTHAM 535 (John Bowring ed., London, Simpkin, Marshall \& Co. 1843).

74. $I d$. at 538 .

75. Id. at 540 .

76. David J. Bederman, The 1871 London Declaration, Rebus Sic Stantibus and a Primitivist View of the Law of Nations, 82 AM. J. INT'L L. 1 (1988).

77. JANIS, supra note 24 , at $50-51$ ("[M]any texts of the sixteenth, seventeenth, and eighteenth centuries described themselves as studies of the "laws of nature and of nations."'); $\mathbf{A}$. Pearce Higgins, Preface to the Seventh Edition of William EDWARD Hall, A TREaTiSE ON INTERNATIONAL LAW, at xiv-xv (7th ed. 1917) ("The older writers from Grotius downward to the 
American pantheon of writers on the law of nations .... [E]arly American judicial decisions implicating the law of nations cited almost exclusively to these Continental writers, and they were quoted quite frequently for propositions about the law of nations ..." writings of these early academics to reveal their conceptions of the law of nations. Subsection II.B.1 discusses Hugo Grotius, whose most influential work was The Law of War and Peace. ${ }^{79}$ Subsection II.B.2 turns to Emmertich Vattel, author of The Law of Nations. ${ }^{80}$ Subsection II.B.3 discusses Samuel von Pufendorf, best known for his seminal work Of the Law of Nature and Nations. ${ }^{81}$ While these three authors focused primarily on the law of nations, William Blackstone, who drafted the famous Commentaries on the Laws of England, ${ }^{82}$ and Montesquieu, author of The Spirit of the Laws, ${ }^{83}$ were regarded as authorities on broader questions of jurisprudence. ${ }^{84}$ The works of these two jurists are discussed in Subsections II.B. 4 and II.B.5, respectively.

\section{Grotius}

Hugo Grotius, author of The Law of War and Peace, has been called "the founder of the Law of Nations of the modern world." 85 He argued that natural law, which was already acknowledged to govern relations between

end of the eighteenth century evolved the rules of international intercourse from the principles of the law of Nature.").

78. Sylvester, supra note 55, at 67; see also Stewart Jay, The Status of the Law of Nations in Early American Law, 42 VAND. L. REV. 819, 823 (1989) ("In ascertaining principles of the law of nations, lawyers and judges of that era relied heavily on continental treatise writers, Vattel being the most often consulted by Americans. An essential part of a sound legal education consisted of reading Vattel, Grotius, Pufcndorf, and Burlamaqui, among others.").

79. 2 HUGo GROTIUS, DE JURE BELli AC PACIS (Francis W. Kelsey trans., William S. Hein \& Co. 1995) (1625).

80. E. De Vattel, The Law of Nations or Principles of the Law of NatUre (Joseph Chitty ed., Philadelphia, T. \& J.W. Johnson \& Co. 1867) (1758).

81. SAMUEl PUfendorf, DE JURE NatURAe ET Gentium (C.H. Oldfather \& W.A. Oldfather trans., William S. Hein \& Co. 1995) (1688).

82. 4 William Blackstone, Commentaries.

83. MONTESQuiEu, THE SPIRIT OF THE LAWS (Anne M. Cohler et al. eds. \& trans., Cambridge Univ. Press 1997) (1748).

84. On Blackstone, see Albert W. Alschuler, Rediscovering Blackstone, 145 U. PA. L. REV. I, 15 (1996) ("Through his Commentaries ... Blackstone taught American Revolutionaries their rights, helped inspire the Declaration of Independence, [and] influenced the deliberations of the Constitutional Convention." (citations omitted)). On Montesquieu, see John C. Yoo, The Continuation of Politics by Other Means: The Original Understanding of War Powers, 84 CAL. L. REV. 167, 199 (1996) ("On questions concerning government and law, eighteenth-century Americans turned to three writers in particular-John Locke, William Blackstone, and Montesquieu.").

85. A. Pearce higgins, Studies in International law and Relations 86 (1928) (discussing "Grotius, whose claim in a very real sense to be the founder of the Law of Nations of the modern world is almost universally admitted"). 
individuals, also controlled intercourse between nations. ${ }^{86}$ His "appeal was so far successful in that it produced the acceptance of a body of rules which were soon acknowledged as the basis of the Law of Nations, and to which in international controversies appeal long continued to be made."

Grotius believed that natural law was ordained by $\operatorname{God}^{88}$ and "unchangeable- even in the sense that it cannot be changed by God." a result, these "eternal, unchangeable" principles had binding force "independent of the special consent of the single States." Grotius was also credited with "secularizing" natural law, because he maintained that it would be the same even if God didn't exist; $;{ }^{91}$ he believed that the substantive content of natural law could be "founded exclusively on reason." 92

People could discover the content of natural law in one of two ways. The first was by a priori reasoning, ${ }^{93}$ the second was through an a posteriori

86. According to one scholarly work on Grotius:

One central doctrine in his treatise was the acceptance of the "law of nature" as an independent source of rules of the law of nations, apart from custom and treaties. The Grotian "law of nature" was to some extent a secularised version, being founded primarily on the dictates of reason, on the rational nature of men as social human beings ....

BURNS H. WESTON ET AL., INTERNATIONAL LAW AND WORLD ORDER 230 (1980); see also JANIS, supra note 24, at 51 (stating that Grotius "looked to a natural law based on right reason"). Similarly, it has been asserted that Grotius

based international law [more accurately, the law of nations] in the main upon a natural law imposed upon man by the requirements of his own nature, of which the cardinal quality, so far as the relation of one man to another is concerned, he supposed to be the social instinct.

Higgins, supra note 77 , at 3 n. 1 .

87. HIGGINS, supra note 85 , at 91 ; see also JANIS, supra note 24 , at 52 (“[T] he object of Grotius' exercise of natural law was to find international rules basic or useful, though not clearly consented to by states.").

88. 2 GROTIUS, supra note 79 , at 38-39 (stating that under natural law, acts are "either forbidden or enjoined by the author of nature, God").

89. 2 id. at 40.

90. 1 OPPENHEIM, supra note 54 , at 88 .

91. See MALCOLM N. SHAW, INTERNATIONAL LAW 21 (4th ed. 1997); see also 1 OPPENHEIM, supra note 54, at 89 ("The modern Law of Nations in particular owes its very existence to the theory of the Law of Nature. Grotius took the decisive step of secularising the law of nature and of emancipating it from purely theological doctrine."); Wolfgang G. Friedmann th al., Historical Introduction, in CASES AND MATERIALS ON INTERNATIONAL LAW 1, 5 (Wolfgang Friedmann et al. eds., 1969) ("Grotius is a rationalist who derives the principles of the law of nature from universal reason rather than from divine authority.").

92. SHAW, supra note 91 , at 21.

93. Grotius wrote:

The law of nature is a dictate of right reason, which points out that an act, according as it is or is not in conformity with rational nature, has in it a quality of moral baseness or moral necessity; and that, in consequence, such an act is either forbidden or enjoined by the author of nature, God.

2 GROTIUS, supra note 79, at 38-39 (citations omitted). He went on to note that a priori reasoning "consists in demonstrating the necessary agreement or disagreement of anything with a rational and social nature." 2 id. at 42. 
examination of the actual practices of civilized nations throughout antiquity, ${ }^{94}$ as described by "the illustrious writers of history." ${ }^{95}$ Grotius's main sources included Aristotle, Cicero, Plutarch, Seneca, Chrysostom, and the Bible. The customs comprising the law of nations were those that had existed throughout most of recorded history. These practices were considered part of the law of nations because they were evidence of natural law, which prohibited acts "in conflict with the nature of society of beings endowed with reason." 96

According to Grotius, the law of nations is that portion of natural law addressing the ways in which one nation may act toward other nations or citizens of other nations, especially in times of war. ${ }^{97}$ It also reaches issues of diplomacy ${ }^{98}$ and treaty formation and interpretation..$^{99}$ No aspects of the law of nations appear to govern the relationship between a nation and its own citizens. Indeed, Grotius explicitly distinguished the law of nations from "municipal law," which "emanates from the civil power... which bears sway over the state." 100

While states may enter into treaties, thereby forming a "volitional law of Nations," ${ }^{101}$ Grotius recognized only a limited range of agreements embraced by this phrase, many of which have to do with ending hostilities. ${ }^{102}$ Grotius called agreements other than peace treaties "[e]qual treaties of alliance," which may "have to do either with commerce, with joint action in war, or with other matters." 103 The "other matters" such treaties may address include guarantees "that neither signatory shall have fortresses in the territory of the other, or defend the subjects of the other, or furnish a passage to the enemy of the other." 104 The other "subject of prime importance" in this volitional law of nations "is the right of legation," governing "the sacred affairs of embassies, [and] the inviolability of

94. According to Grotius, a principle is likely to be consistent with "the law of nature [if it] is believed to be such among all nations, or among all those that are more advanced in civilization. ... [T]he cause of such an opinion can hardly be anything else than the feeling which is called the common sense of mankind." 2 id. at 42.

95. 2 id. at 44.

96. $2 \mathrm{id}$. at 34 . Grotius wrote that "unbroken custom" was "proof [of] the law of nations." 2 id. at 44 (emphasis added).

97. See 2 id. at 44 ("[O]utside of the sphere of the law of nature, which is also frequently called the law of nations, there is hardly any law common to all nations."); see also 2 id. at 57 ("[N]ot all wars are at variance with the law of nature; and this may also be said to be true of the law of nations.").

98. See 2 id. at $438-49$.

99. See 2 id. at $391-429$.

100. 2 id. at 44 .

101. See $2 \mathrm{id}$. at 438 (comparing "rights for which we are indebted to the law of nature" to those stemming from "the volitional law of nations").

102. See $2 \mathrm{id}$. at $394-96$ (discussing peace treaties on equal and unequal terms).

103. $2 \mathrm{id}$. at 395.

104. $2 \mathrm{id}$. at $395-96$. 
ambassadors." 105 Thus, the range of treaties recognized as comprising part of the law of nations was limited. In short, Grotius's treatise on the law of nations offers little, if any, support for an expansive interpretation of the phrase.

\section{Vattel}

Vattel is often categorized as belonging to the Grotian, or eclectic, school of international law ${ }^{106}$ because he looked to both natural and positive law as sources for the law of nations, ${ }^{107}$ although he has also been termed a naturalist. ${ }^{108}$ In The Law of Nations, Vattel echoed many of Grotius's points. He noted that " $[\mathrm{t}]$ he law of Nations is originally no other than the law of Nature applied to Nations." 109 While the law of nature govems the interactions of individuals, the law of nations governs the interactions among states. ${ }^{110}$ Vattel cautioned, however, that although the general principles of the two bodies of law are the same, their precise applications may not be.

[W]e are not to imagine that the law of nations is precisely and in every case the same as the law of nature.... A state or civil society is a subject very different from an individual .... There are many cases, therefore, in which the law of Nature does not decide between state and state in the same manner as it would between man and man. ${ }^{11}$

Vattel asserted that the law of nations is both unalterable and mandatory. "Whence, as this law is immutable, and the obligations that arise from it necessary and indispensable, nations can neither make any changes in it by their conventions, dispense with it in their own conduct, nor reciprocally release each other from the observance of it." ${ }^{, 112}$ As this passage implies, the law of nations governs treaties much as contract law

105. 2 id. at 438.

106. D.J. HARRIS, CASES AND MATERIALS ON INTERNATIONAL LAW 57 (5th ed. 1998).

107. WILLIAM L. TUNG, INTERNATIONAL LAW IN AN ORGANIZING WORLD 17 (1968).

108. STERLING E. EDMUNDS, THE LAWLESS LAW OF NATIONS 36 (1925).

109. VATTEL, supra note 80 , at 53.

110. According to Vattel, there is a

Necessary Law of Nations which consists in the application of the law of nature to Nations. It is Necessary because nations are absolutely bound to observe it. This law contains the precepts prescribed by the law of nature to States, on whom that law is not less obligatory than on individuals. Id. at 54-55.

111. Id. at 53 .

112. Id. at 55 . 
governs individual contracts. ${ }^{113}$ Moreover, it establishes bounds on the permissible substantive content of treaties. "[E]very treaty, every custom, which contravenes the injunctions or prohibitions of the Necessary law of nations is unlawful."114 Vattel's "lack of interest in treaty or custom is telling of the unimportance that these areas of law played for jurists of Vattel's time-including American jurists-and is an important indicator of the vast gulf between eighteenth and later nineteenth-century conceptions of the law of nations." 115

Vattel distinguished between what he termed the "necessary law of nations," described above, and the positive law of nations. Whereas the former is immutable, being "founded on the nature of things, and particularly on the nature of man," the latter "proceed[s] from the will of Nations." 116 The positive law of nations arises from treaties and international custom. Vattel stressed, "As to the rights introduced by Treaties or by Custom, there is no room to apprehend that any one will

113. Id. at 291 (stating that under the law of nations, nations "ought invariably to observe their promises and their treaties"). This raises a potential argument in favor of an interpretation of the Offenses Clause that would expand its scope to treaties and international agreements. One might claim that it does not matter whether intemational agreements are part of the law of nations, because the law of nations requires nations to keep all of their promises. Consequently, the Offenses Clause enables Congress to enforce such agreements. This argument is flawed in several respects. First, as an empirical matter, many international agreements are aspirational rather than mandatory. That is, while they express general goals of the international community, they do not give rise to legal obligations on the part of individual nations. Failure to pursue these goals would neither constitute a violation of these agreements nor mean that our nation broke a promise. See, e.g., Irene Scharf, Kosovo's War Victims: Civil Compensation or Criminal Justice for Identity Elimination?, 14 EMORY INT'L L. REV. 1415, 1427 (2000) (arguing that the Universal Declaration of Human Rights "does not have the force of a treaty; rather, it is hortatory and aspirational, recommendatory rather than formally binding" (internal quotes and citation omitted)); Carlos Manuel Vazquez, Response: Laughing at Treaties, 99 COLUM. L. REV. 2154, 2183 (1999) (stating that a "precatory or aspirational" treaty does not purport to obligate the parties to do anything in particular"). Thus, given the current state of intemational law, this interpretation of the law of nations would not grant Congress sweeping new powers.

Second, the language of the Offenses Clause itself seems to preclude such an interpretation. If particular treaties are not part of the law of nations, then an individual who acts contrary to their terms does not violate the law of nations (though he would, of course, violate international law). Such an act might cause the United States to be in violation of its duty under the law of nations to keep its promises, but it does not mean that the individual has committed a violation against the law of nations. Consequently, the Offenses Clause could not support the passage of legislation to prevent such acts.

Finally, such an interpretation is undermined by the Alien Tort Claims Act (ATCA), enacted by the first Congress in 1789, which grants federal courts jurisdiction over claims brought by aliens alleging torts "committed in violation of the law of nations or a treaty of the United States." Judiciary Act of 1789, ch. $20, \S 9$ (b), 1 Stat. 73, 76-77. If the law of nations encompassed all U.S. treaties, there would have been no need to mention them separately in the ATCA. Thus, the Offenses Clause does not permit Congress to enforce domestically treaties that are not part of the law of nations-that is, treaties that regulate the relationship between the government and its citizens, or that fall outside the substantive areas that the law of nations governs.

114. VATTEL, supra note 80 , at 55.

115. Sylvester, supra note 55, at 72 (citations omitted).

116. VATTEL, supra note 80 , at 55. 
confound them with the Natural law of nations." 117 Throughout his work, however, when discussing the "law of nations," he most often refers to what he initially terms the natural law of nations.

Among the topics for which Vattel sets forth the substantive directives of the law of nations are "mutual commerce between nations," "rules respecting foreigners," ${ }^{119}$ and treaties. ${ }^{120}$ Much of the remainder of his book is dedicated to questions of war and diplomacy. It is important to recognize that those few chapters discussing wholly domestic topics, such as "cultivation of the soil," nations. Vattel recognized that the law of nations-whether positive or natural-dealt with nations' interactions with each other. ${ }^{122}$

\section{Pufendorf}

Pufendorf did not believe that any international norms or agreements were part of the law of nations. ${ }^{123} \mathrm{He}$ "exceeded the devotion of [Grotius] to the Law of Nature, and abandoned or denied the claim of the positive Law of Nations founded on custom or treatises to the name." 24 In Of the Law of Nature and Nations, Pufendorf wrote, "Nor do we feel that there is any other voluntary or positive law of nations which has the force of a law, properly so called, such as binds nations." 125

Pufendorf grounded his conception of natural law in theology to a far greater extent than either Grotius or Vattel. To Pufendorf, "[w]ithout God there could be no law because there would be no lawgiver; nor, because God's law is the source of moral obligation, could there be moral relations among humankind." 126 He wrote, "[T]he obligation of natural law is of

117. Id.

118. VATTEL, supra note 80 , at 224-31.

119. Id. at 260-71.

120. Id. at 287-375.

121. Id. at 102-04.

122. Id. at 213 .

123. HERSHEY, supra note 57 , at 59 ("Pufendorf ... denied the existence of any positive International Law based on custom and treaties, and maintained that the Law of Nations is wholly a part of the Law of Nature.").

124. HigGINs, supra note 85 , at 92.

125. PUFENDORF, supra note 81 , at 226. In stressing that the law of nations excludes treaties and customs, Pufendorf states that "if a man who is waging a legitimate war" neglects customary international norms, "he may be accused of no fault other than a kind of ungentlemanliness." $I d$. at $227-28$.

126. Craig L. Carr \& Michael J. Seidler, Pufendorf, Sociality and the Modern State, 17 HIST. POL. THOUGHT 354, 358 (1996), reprinted in GROTIUS, PUFENDORF AND MODERN NATURAL LAW 133, 137 (Knud Haakonssen ed., 1999); see also STEPHEN BUCKLE, NATURAL LAW AND THE THEORY OF PROPERTY: GROTTUS TO HUME 62 (1991) ("Pufendorf parts company with Grotius on the question of the ultimate foundation of the law of nature. The law of nature is not, he says, independent of the divine will."). But see T.J. HOCHSTRASSER, NATURAL LAW THEORIES 
God, the creator and final governor of mankind, who by His authority has bound men, His creatures, to observe it." ${ }^{127}$ Thus, Pufendorf adopted Hobbes's conception of the law of nations, seeing "natural law as being imposed by a divine injunction, analogous apparently to the injunctions of religion, and as not being binding apart from such injunction." 128

Nonetheless, like Blackstone and Grotius, Pufendorf believed that the content of these divine imperatives are deducible by natural reason. ${ }^{129}$ "His concept of the law of nature embraced those standards of behavior that experience and reason... showed men ... to be essential for their own good and for the good of human society of which they formed a part in accordance with the design of nature." ${ }^{30}$ Thus, of the philosophers discussed in this Section, Pufendorf argues for the closest link between the law of nations and natural law and most emphatically rejects the notion that the law of nations could be affected by evolving international norms.

\section{Blackstone}

Blackstone had a very strong influence on the Framers. ${ }^{131}$ He dedicated an entire chapter of his Commentaries to "offences against the law of nations." 132 He opened his discussion with the claim that "the law of nations is a system of rules, deducible by natural reason, and established by universal consent among the civilized inhabitants of the world."133 Elsewhere in his analysis, Blackstone argued that the law of nations stems from "those principles of natural justice, in which all the learned of every nation agree," 134 reaffirming the natural law roots of this concept. He does not explain, however, how a nation would go about withholding its consent from this "great universal law"; Blackstone did not imply that the law of nations would cease to be binding if nations attempted to do so.

Blackstone stressed that the law of nations "is founded upon this principle, that different nations ought in time of peace to do one another all the good they can; and, in time of war, as little harm as possible, without prejudice to their own real interests." 135 The best interpretation of his analysis is that human reason inexorably leads to the adoption of a specific

IN THE EARLY ENLIGHTENMENT 62 (2000) (arguing that Pufendorf's natural law "avoids reference ... to divine institution" and is "grounded solely on a calculation of self-preservation").

127. PUFENDORF, supra note 81 , at 217.

128. Higgins, supra note 77 , at 2 n.l.

129. PUFENDORF, supra note 81 , at 226.

130. GLAHN, supra note 62, at 31-32.

131. See Alschuler, supra note 84 , at 15.

132. 4 BLACKSTONE, supra note 82 , at *66.

133. 4 id.

134. 4 id. at $* 67$.

135. 4 id. at $* 66$. 
and discrete set of principles-the law of nations-which facilitate "intercourse or commerce between one nation and another." 136

Blackstone noted that the law of nations prohibits certain offenses "committed by one independent people against another" and governs "mercantile questions" as well as admiralty disputes. ${ }^{137} \mathrm{He}$ went on to identify three specific types of offenses against the law of nations: "The principal offences against the law of nations ... are of three kinds; 1. Violation of safe-conducts; 2. Infringement of the rights of embassadors; and, 3. Piracy." 138 In Blackstone's view, the law of nations does not govern the relationship between a government and its citizens except insofar as is necessary to protect foreign nations or foreign nationals. Moreover, he does not suggest that the law of nations extends much beyond these specifically identified areas. For this reason, Blackstone's commentary in this area constitutes persuasive evidence against a broad reading of the Offenses Clause.

\section{Montesquieu}

In The Spirit of the Laws, Montesquieu wrote of le droit des gens, which can be translated as either "law of nations" or "right of nations."139 He distinguished between le droit des gens, which concerned laws "bearing on the relation" between "the different peoples of the planet," and le droit politique, which concerned the governors and the governed in a particular society. ${ }^{140}$

Montesquieu echoed Blackstone in stating that "the right of nations is by nature founded on the principle that various nations should do to one another in times of peace the most good possible, and in times of war the least ill possible, without harming their true interests." Montesquieu goes on to explain that "[t]he object of war is victory; of victory, conquest; of conquest, preservation. All the laws that form the right of nations should derive from this principle and the preceding one."141

Though he mentioned the right of nations a few times later in The Spirit of the Laws, this was Montesquieu's only exposition of the phrase. Montesquieu did not specify whether the right of nations stems from God's

136. 4 id. at *68.

137. 4 id. at *67-68.

.138. 4 id. at *68.

139. The original eighteenth-century translation of Montesquieu rendered this phrase as "law of nations." MONTESQUIEU, THE SPIRIT OF LAWS: A COMPENDIUM OF THE FIRST ENGLISH EDITION 103 (David Wallace Carithers ed., 1977) (1748). However, the most recent scholarly version uses "right of nations" instead. MONTESQUIEU, supra note 83, at 7.

140. MONTESQUIEU, supra note 83, at 7.

141. Id. at 7-8; see also 4 BLACKSTONE, supra note 82 , at *66. 
will, human reason, custom, or some other origin. He merely claimed that specific mandates were logically derivable from the principles he articulated. However, in explicitly distinguishing the right of nations from political law, which governs domestic affairs, and defining the law of nations in terms of countries' interactions with each other, Montesquieu's theory makes an expansive interpretation of the Offenses Clause less plausible.

Having explored the attitudes of philosophers whose work shaped the Framers' understanding of the phrase "law of nations," I will now examine how early American courts interpreted it.

\section{Early Courts and the Law of Nations}

The influence of the scholars discussed in the previous Section can be seen in early American court rulings interpreting the phrase "law of nations." The frequency with which courts cited these commentators in the years after the Founding is indicative of their influence over American thought in this area. ${ }^{142}$ For example, the Supreme Court accepted Vattel's trichotomy among different branches of the positive law of nations almost verbatim. ${ }^{143}$

In 1792, the chief justice of the Pennsylvania Supreme Court recognized the immutability of the law of nations and its relationship to natural law:

[T] he law of nations, or of nature and reason, is in arbitrary states enforced by the royal power, in others, by the municipal law of the country; which latter may, I conceive, facilitate or improve the execution of its decisions, by any means they shall think best, provided the great universal law remains unaltered. ${ }^{144}$

142. According to LEXIS searches of state and federal court rulings from 1775 through 1810 , Grotius was cited in 29 cases, Vattel in 71, Blackstone in 248 (though mostly for matters of English common law rather than the law of nations), and Montesquieu in 6. Pufendorf, however, was cited only once, and then indirectly. See Den ex dem. Tucker v. White, 1 N.J.L. 111, 119 (1791).

143. In Ware v. Hylton, the Court wrote:

The law of nations may be considered of three kinds, to wit, general, conventional, or customary. The first is universal, or established by the general consent of mankind, and binds all nations. The second is founded on express consent, and is not universal, and only binds those nations that have assented to it. The third is founded on tacit consent; and is only obligatory on those nations who have adopted it.

3 U.S. (3 Dall.) 199, 227 (1796). Vattel carefully distinguished the positive law of nations from the natural, or necessary, law of nations. VATTEL, supra note 80, at 63 .

144. Ross v. Rittenhouse, 2 U.S. (2 Dall.) 160, 162 (Pa. 1792) (McKean, C.J.). 
Early American courts understood the law of nations as a set of rules, either related to or derived from natural law, concerning the ways in which nations were to act toward each other. ${ }^{145}$ The United States, by declaring independence and entering onto the international stage, became subject to its moral dictates. ${ }^{146}$

The list of offenses that American courts from 1775 through 1810 recognized as being contrary to the "law of nations" is entirely consistent with those identified by the scholars discussed in the preceding Section. Early cases recognizing violations of the law of nations can be grouped into four areas: ${ }^{147}$

(1) Navigation: governing conduct on the high seas ${ }^{148}$ and incorporating rules of capture ${ }^{149}$ and salvage at sea. ${ }^{50}$

145. Geyer v. Michel, 3 U.S. (3 Dall.) 285, 292 (1796) ("I gave a like decision lately, in the case of the schooner Nancy, from a full conviction that the principles I laid down formerly, were founded on the rules of propriety and the laws of nations." (quoting Moodie v. The Betsey Cathcart, 17 F. Cas. 651 (D.S.C. 1795) (No. 9742)) (emphasis omitted)). Similarly, in Miller v. The Ship Resolution, the court stated:

It is a maxim of the law of nations, founded on every principle of reason, justice and morality, that one nation ought not to do an injury to another. As the natural state (that of nations) is a state of peace and benevolence, nations are morally bound to preserve it.

2 U.S. (2 Dall.) 1, 3 (Fed. Ct. App. 1781).

146. See Ware, 3 U.S. (3 Dall.) at 281 ("When the United States declared their independence, they were bound to receive the law of nations, in its modern state of purity and refinement." (emphasis omitted)); Chisholm v. Georgia, 2 U.S. (2 Dall.) 419, 474 (1793) ("[T] The United States had, by taking a place among the nations of the earth, become amenable to the laws of nations; and it was their interest as well as their duty to provide, that those laws should be respected and obeyed....").

147. Cf. Jay, supra note 78 , at 821-22 ("In its broadest usage, the law of nations comprised the law merchant, maritime law, and the law of conflicts of laws, as well as the law governing the relations between states.").

148. Chisholm, 2 U.S. (2 Dall.) at 475 ("[A]s the seas are the joint property of nations, whose right and privileges relative thereto, are regulated by the law of nations and treaties, such cases necessarily belong to national jurisdiction."); Talbot v. Commanders \& Owners of Three Brigs, 1 U.S. (1 Dall.) 95, 101 (Pa. High Ct. Err. \& App. 1784) (recognizing the "maritime law of nations").

149. McDonough v. Dannery, 3 U.S. (3 Dall.) 188, 193 (1796) ("The vessel had been British-of this, there is no question; did she, by capture and firm possession, according to the law of nations, bccome French?"); The Ship Resolution, 2 U.S. (2 Dall.) at 22-23 (“[T]he seizure and capture, in the present case, was a violence at all events justified by the law of nations, and for which no action would lie ....").

150. Regarding salvage at sea, the early Court stated:

Several of the Roman emperors made their edicts and decrees for the preservation of [marooned ships and] property, and the restoration of it; and for a long time, the law of nations has been settled on principles consonant to justice and humanity, in favor of the unfortunate proprietors [whose property was lost at sea].

McDonough, 3 U.S. (3 Dall.) at 190. 
(2) Rules of War: often focusing on the right of one country to seize property from or alter the legal rights of citizens of an enemy country. ${ }^{151}$

(3) Commercial Activities: incorporating mercantile law, ${ }^{152}$ and often resolving conflict of laws issues. ${ }^{153}$

(4) International Relations: encompassing the rules governing treaties, ${ }^{154}$ interactions between nations, and interactions between a

151. Ware, 3 U.S. ( 3 Dall.) at 226 ("[E]very nation at war with another is justifiable, by the general and strict law of nations, to seizc and confiscate all moveable property of its enemy (of any kind or nature whatsoever) wherever found ...."); United States v. Peters, 3 U.S. (3 Dall.) $121,130(1795)$ (" $[\mathrm{B}] \mathrm{y}$ the laws of nations, the vessels of war of belligerent powers [enjoy certain privileges]."); Hoare v. Allen, 2 U.S. (2 Dall.) 102, 103 (Pa. 1789) (stating that from 1775 to 1783 , "the defendant [an American] could not have paid this money to the [British] plaintiff, who was an alien enemy, without a violation of the positive laws of this country, and of the laws of nations"); Wilcox v. Henry, 1 U.S. (1 Dall.) 69, 71 (Pa. 1782) ("An alien enemy has no right of action whatever during the war ... but by the law of nations, confirmed by universal usage, at the end of the war, all the rights and credits, which the subjects of either power had against the other, are revived....").

152. Steinmetz v. Currie, 1 U.S. (I Dall.) 270, 270 (Pa. 1788) (recognizing the "general mercantile law of nations").

153. In Banks v. Greenleaf, when faced with a situation where the laws of individual countries were "contradictory to each other," the court asked, "What, then, says the law of nations upon this subject?" 2 F. Cas. 756, 757 (C.C.D. Va. 1799) (No. 959). It concluded that under the law of nations, "the law of the country where the contract is made shall prevail; and if the law of a foreign country be inconsistent with ours, ours shall prevail." Id. at 757 .

154. The Supreme Court has held:

It is a part of the law of nations, that if a treaty be violated by one party, it is at the option of the other party, if innocent, to declare, in consequence of the breach, that the treaty is void.... But the same law of nations tells me, that until that declaration be made [by Congress that the treaty is to be voided], I must regard it (in the language of the law) valid and obligatory.

Ware, 3 U.S. (3 Dall.) at 261. Similarly, in The Ship Resolution, a federal court ruled:

[A]lthough, on a decree of acquittal, almost the whole cargo will go into the hands of those who are not the friends of America ... [yet] they are entitled to [the cargo], by the articles of capitulation, which bind America, the law of nations operating on those articles as a solemn compact, commands that such a decree must be given.

2 U.S. (2 Dall.) at 33. 
nation's citizens and a foreign nation, its envoys, ${ }^{155}$ citizens, ${ }^{156}$ officials, ${ }^{157}$ or ships. ${ }^{158}$

Professor Stephens argues that the Offenses Clause can serve as the basis for legislation regulating the relationship between the federal government and individual Americans. I have been unable to find any early American case applying the law of nations to such matters. Similarly, although Professor Stephens maintains that the phrase "law of nations" is synonymous with "international law" (which includes treaties), the courts of the time repeatedly noted the distinction between treaties and the law of nations, suggesting these areas are not coextensive. ${ }^{159}$ Even attorneys of this period seemed to assume without argument or explanation that the law of nations was distinct from treaties. ${ }^{160}$

Having examined the attitude that early, precedent-setting American courts took toward the phrase "law of nations," the next Section turns to a brief overview of the original understanding of the Framers of the Constitution.

155. United States v. Benner, 24 F. Cas. 1084, 1086 (C.C.E.D. Pa. 1830) (No. 14,568) (jury charge) ("In the reception of ambassadors and ministers, the president is the government ... and by the act of reception, the person so received, becomes at once clothed with all the immunities which the law of nations and the United States, attach to the diplomatic character."); Bolton v. Martin, 1 U.S. (1 Dall.) 296, 300 (C.P. Phila, 1788) ("[T]he privilege which the law of nations confers upon Ambassadors, is not the result of any particular form of government...."); Respublica v. De Longchamps, 1 U.S. (1 Dall.) 111, 116 (Ct. Oyer \& Terminer Phila. 1784) ("The person of a public minister is sacred and inviolable. Whoever offers any violence to him, not only affronts the sovereign he represents, but also hurts the common safety and well-being of nations he is guilty of a crime against the whole world.").

156. See Hoare, 2 U.S. (2 Dall.) at 103 (holding that the law of nations prevented the American defendant from repaying his British creditor during the Revolution).

157. See De Longchamps, 1 U.S. (1 Dall.) at 115.

158. Talbot v. Jansen, 3 U.S. ( 3 Dall.) 133, 158 (1795) ("It is an act of justice, resulting from the law of nations, to restore to the friendly power the possession of his vessel, which a citizen of the United States illegally obtained ....").

159. See Ware, 3 U.S. (3 Dall.) at 281 ("There are two points involved in the discussion of this power of confiscation: the first arising from the rule prescribed by the law of nations; and the second arising from the construction of the treaty of peace."); Talbot, 3 U.S. (3 Dall.) at 155 ("The United States would, perhaps, be bound, both by the law of nations and an express stipulation in their treaty with the Dutch, to restore such captured vessels, when brought within their jurisdiction ...."); United States v. Peters, 3 U.S. (3 Dall.) 121, 129 (1795) ("[W]hereas, by the laws of nations, and the treaties subsisting between the United States and the Republic of France, the trial of prizes taken on the high seas, without the territorial limits and jurisdiction of the United States . . belong[s] to the tribunals [of the United States] . ...").

160. See, e.g., United States v. Lawrence, 3 U.S. (3 Dall.) 42, 45 (1795) (stating that counsel argued that " $[t]$ he treaty has placed the subject in controversy upon a footing different from the law of nations; for, independently of positive compact, no government will surrender deserters or fugitives who make an asylum of its territory"). 


\section{The Framers, Natural Law, and the Law of Nations}

Natural law strongly influenced the Constitution's Framers. ${ }^{161}$ "The reality of natural law was taken for granted by Americans of the Revolutionary era and of the years in which the Constitution was framed and ratified.... [T] he Framers of the Constitution in $1787 \ldots$ accepted the concept of natural law presented by Blackstone." ${ }^{162}$ The law of nations was an outgrowth of this conception of natural law. "[M]ost Founding-era political thought adopted the view that the law of nations was a branch of the law of nature and thus imposed a set of higher-law limitations on all nations." 163

James Wilson, an active participant in the Constitutional Convention, is well known for his extensive discourses on the meaning of the term. He stated, "The law of nations, as well as the law of nature, is of obligation indispensable: the law of nations, as well as the law of nature, is of origin divine. ... Universal, indispensable, and unchangeable is the obligation of both." 164 This belief that the law of nations had a definite content that Congress could not itself determine seems to have been accepted at the Convention. At one point in the brief debate over the Offenses Clause, Wilson remarked, "To pretend to define the law of nations which depended on the authority of all the civilized nations of the world, would have a look of arrogance, that would make us ridiculous." ${ }^{165}$ Gouverneur Morris assuaged his concerns, responding that the law of nations was "often too vague and deficient to be a rule" enforceable in courts of law, and so "[t]he word define is proper." 166

161. See supra text accompanying note 77. See generally Terry Brennan, Natural Rights and the Constitution: The Original "Original Intent," 15 HARV. J.L. \& PUB. POL'Y 965 (1992) (discussing the importance of natural law theories to the framing of the Constitution).

162. Russell Kirk, Natural Law and the Constitution of the United States, 69 NOTRE DAME L. REV. 1035, 1038-39 (1994); see also Sylvester, supra note 55, at 65 ("To the Founding generation, law, based on natural law, reason, or established principles, was a matter of universal applicability.").

163. Note, Restructuring the Modern Treaty Power, 114 HARV. L. REV. 2478, 2492 (2001); see also Jules Lobel, The Limits of Constitutional Power: Conflicts Between Foreign Policy and International Law, 71 VA. L. REv. 1071, 1078 (1985) ("The generation that fought the American Revolution and drafted the Constitution generally believed in an unwritten 'higher' law imposing legal restraints on governmental power. Courts and scholars viewed international law as a crucial component of that fundamental natural law.").

164. JAMES WILSON, Of the Law of Nations, in 1 THE WORKS OF JAMES WILSON 148, 14951 (Robert Green McCloskey ed., 1967).

165. JAMES MADison, THE DEBATES IN THE FEDERAL CONVENTION OF 1787 Which FRAMED THE CONSTITUTION OF THE UNTTED STATES OF AMERICA 563 (Gaillard Hunt \& James Brown Scott eds., 1920) (reporting for September 14, 1787).

166. Id. 
A variety of early sources recognized the distinction between the law of nations and treaties. ${ }^{167}$ This is most clearly evidenced by the Alien Tort Claims Act, a statute enacted in 1789 by a Congress composed of the Framers' contemporaries. The Act granted federal courts jurisdiction over claims brought by aliens for "torts committed in violation of the law of nations or of a treaty of the United States." 168

The Federalist not only recognized this distinction ${ }^{169}$ but argued that the former in fact governed the latter. If the President and Senate conspired to form a "corrupt" treaty, "like all other fraudulent contracts, [it would] be null and void by the law of nations." $" 170$ It was also strongly suggested that the law of nations would not apply to disputes between a government and its own citizens. John Jay wrote, for instance, that "[i]t is of high importance to the peace of America that she observe the laws of nations toward all these Powers [foreign countries]."

St. George Tucker, in his 1803 book on Blackstone's Commentaries and the U.S. Constitution, specifically cited the Offenses Clause, writing, "Under this head, of offences against the law of nations, the violation of the rights of ambassadors, as also of passports, and safe conducts is included." 172 Tucker further discussed

the very guarded manner in which congress are vested with authority [under the Offenses Clause] to legislate upon the subjects of crimes, and misdemeanors. They are not entrusted with a general power over these subjects, but a few offences are selected from the great mass of crimes with which society may be infested, upon which, only congress are authorized to prescribe the punishment, or define the offence. ${ }^{13}$

Three decades later, this sentiment was echoed by Chancellor James Kent, who wrote that the law of nations is "that code of public instruction which defines the rights and prescribes the duties of nations in their

167. Perhaps most notably, the Alien Tort Claims Act gave federal district courts jurisdiction over actions brought by aliens for torts "committed in violation of the law of nations or a treaty of the United States." 28 U.S.C. $\$ 1350$ (1994); see also 9 JAMES MADISON, PAPERS 384 (William T. Hutchinson et al. cds., 1975) (worrying that states would "violate treaties and the law of nations").

168. Judiciary Act of 1789 , ch. $20, \$ 9$ (b), 1 Stat. $73,76-77$.

169. THE FEDERALIST No. 3, at 43 (John Jay) (Clinton Rossiter ed, 1961) (discussing "treaties and articles of treaties, as well as the laws of nations").

170. THE FEDERALIST No. 64, supra note 169, at 395 (John Jay).

171. THE FEDERALIST No. 3, supra note 169 , at 43 (John Jay).

172. 1 ST. GEORGE TUCKER, BLACKSTONE'S COMMENTARIES WITH NOTES OF REFERENCE TO THE CONSTITUTION AND LAWS OF THE FEDERAL GOVERNMENT OF THE UNITED STATES AND OF THE COMMONWEALTH OF VIRGNIA app. at 268-69 (photo. reprint 1996) (Philadelphia, William Young Birch \& Abraham Small 1803).

173. 1 id. app. at 269 . 
intercourse with each other." ${ }^{174}$ Kent stressed the continuing importance of the natural law tradition to the law of nations. He wrote that while

the most useful and practical part of the law of nations is, no doubt, instituted or positive law, founded on usage, consent, and agreement... it would be improper to separate this law entirely from natural jurisprudence, and not to consider it as deriving much of its force and dignity from the same principles of right reason... as those from which the science of morality is deduced. ${ }^{175}$

Moreover, Kent adopted Blackstone's conception of "offenses against the law of nations," stating that "[t]he offenses which fall more immediately under its cognizance, and which are the most obvious, the most extensive, and most injurious in their effects, are the violations of safe-conduct, infringements of the rights of ambassadors, and piracy." 176

While a more thorough examination of the Framers' beliefs is beyond the scope of this Note, this Section provides credible evidence that the understanding of the term "law of nations" promulgated by scholars and accepted by courts was also shared by the people who drafted and ratified the Constitution. Having looked to the past to clarify the meaning of this phrase, the next Section shows that this understanding is entirely consistent with judicial interpretations of the Offenses Clause through the modern day.

\section{E. Federal Courts and the Offenses Clause}

Courts have not frequently discussed the Offenses Clause over the past 150 years, nor has Congress cited it as the basis for many pieces of legislation. ${ }^{177}$ Cases in which courts have cited the Clause as the primary basis for legislation appear to fall exclusively into three categories. First, the Clause has most commonly been invoked as the justification for statutes prohibiting picketing or protests in the vicinity of embassies. ${ }^{178}$ It has also been interpreted as empowering Congress to establish military commissions to try violations of the law of war, ${ }^{179}$ which the Supreme Court has

174. 1 JAMES KENT, COMMENTARIES ON AMERICAN LAW 1 (photo. reprint 1989) (O.W. Holmes, Jr., ed., Fred B. Rothman \& Co. 1873).

175. 1 id. at 2.

176. 1 id. at $182-83$.

177. For the short list of statutes enacted by Congress pursuant to its authority under the Clause, see Posner \& Spiro, supra note 14 , at 1225 n. 75.

178. Finzer v. Barry, 798 F.2d 1450, 1455 (D.C. Cir. 1986) (citing Vattel for the proposition that the law of nations governed the protection of diplomats), rev'd on other grounds sub nom. Boos v. Barry, 485 U.S. 312 (1988); Frend v. United States, 100 F.2d 691, 692 (D.C. Cir. 1938); Jewish Def. League v. Washington, 347 F. Supp. 1300, 1301 (D.D.C. 1972).

179. In Ex parte Quirin, the Court held that Congress had 
recognized as an important branch of the law of nations. ${ }^{180}$ Finally, courts have read it to permit prohibitions on the counterfeiting of foreign currencies. $^{181}$

All of these cases fit neatly into the framework discussed in the preceding Sections. They deal with the prevention of substantive harm by Americans to foreign countries, or by foreigners to America. The conduct at issue in these cases-harassing diplomats, engaging in war crimes, and counterfeiting foreign securities-would have been recognized as offenses against the law of nations by the Framers and the philosophers who influenced them. In United States $v$. Arjona, the Court stated:

The law of nations requires every national government to use "due diligence" to prevent a wrong being done within its own dominion to another nation with which it is at peace, or to the people thereof; and because of this the obligation of one nation to punish those who within its own jurisdiction counterfeit the money of another nation has long been recognized. ${ }^{182}$

The Court did not claim that the law of nations in any way regulated the conduct of a government toward its own citizens. Accordingly, my explanation of the correct understanding of the Offenses Clause is consistent with the case law interpreting it.

In this Part, I have laid out the evidence for what I believe to be the most accurate interpretation of the phrase "law of nations" as used in the Offenses Clause. ${ }^{183}$ The next Part discusses an alternative, compromise interpretation of the phrase, which remains true to many of the principles underlying this concept while nonetheless allowing for the incorporation of certain fundamental modern norms.

exercised its authority to define and punish offenses against the law of nations by sanctioning, within constitutional limitations, the jurisdiction of military commissions to try persons for offenses which, according to the rules and precepts of the law of nations, and more particularly the law of war, are cognizable by such tribunals.

317 U.S. 1, 28 (1942); see also In re Yamashita, 327 U.S. 1, 7 (1946) (citing Quirin for the constitutionality of military commissions to try war crimes).

180. See In re Yamashita, 327 U.S. at 7 (holding that "the law of war is a part" of the law of nations).

181. United States v. Arjona, 120 U.S. 479 (1887); see also United States v. White, 27 F. 200 (C.C.E.D. Mo. 1886) (holding that the Offenses Clause allows Congress to prohibit the counterfeiting of foreign currencies).

182. Arjona, 120 U.S. at 484.

183. Indeed, at one point in her argument Stephens appears to endorse this conception of the phrase, characterizing the law of nations as "equally available to and equally binding upon all nations of the world. Moreover, as the law of all nations, no one State could tamper with or amend its content." Stephens, supra note 14, at 464. Instead of pursuing the implications of this definition, however, she maintains the assumption that the phrase is nonetheless equivalent to "international law." See supra text accompanying note 24. 


\section{LAW OF NATIONS AS JUS COGENS AND THE ALIEN TORT CLAIMS ACT}

Aside from the Offenses Clause, the other major place in U.S. law where the phrase "law of nations" appears is in the Alien Tort Claims Act (ATCA). The ATCA vests federal district courts with jurisdiction over any claim, brought by an alien, of a tort "committed in violation of the law of nations or a treaty of the United States." 184 Because this statute was enacted in 1789 by many of the same people who had drafted or ratified the Constitution, judicial interpretations of it might also inform interpretations of parallel language in the Offenses Clause. ${ }^{185}$

The Supreme Court has never given a definitive interpretation of the ATCA. Throughout most of the 1960 s and 1970s, courts interpreted the Act to exclude claims brought by aliens against their own governments ${ }^{186}$ because the phrase "law of nations" was thought to only "govern[] civilized states in their dealings with each other." ${ }^{" 187}$ One court explicitly held:

[A] violation of the law of nations arises only when there has been "a violation by one or more individuals of those standards, rules or customs (a) affecting the relationship between states or between an individual and a foreign state, and (b) used by those states for their common good and/or in dealings inter se." ${ }^{188}$

This narrow conception of the law of nations, which was in many ways consistent with the Framers' original intent, was rejected in the celebrated case of Filartiga v. Pena-Irala. ${ }^{189}$ In Filartiga, the Second Circuit held that the phrase "law of nations," as used in the ATCA, referred to all violations of modern international customary norms. ${ }^{190}$ Many courts followed this

184. 28 U.S.C. $\S 1350(2000)$.

185. Judiciary Act of 1789 , ch. $20, \S 9$ (b), 1 Stat. 73, 76-77 (providing that federal district courts shall "have cognizance ... of all causes where an alien sues for a tort only in violation of the law of nations or a treaty of the United States").

186. Dreyfus v. Von Finck, 534 F.2d 24, 30-31 (2d. Cir. 1976) ("There has been little judicial interpretation of what constitutes the law of nations .... There is a general consensus, however, that it deals primarily with the relationship among nations rather than among individuals."); Valanga v. Metro. Life Ins. Co., 259 F. Supp. 324, 328 (E.D. Pa. 1966) ("A violation of the law of nations means a violation of those standards by which nations regulate their dealings with one another inter se.").

187. Dreyfus, 534 F.2d at 31; see also Banco Nacional de Cuba v. Sabbatino, 376 U.S. 398, 442 (1964) (White, J., dissenting) (noting that international law had not been violated in cases where the parties were nationals of the acting state).

188. IIT v. Vencap, Ltd., 519 F.2d 1001, 1015 (2d Cir. 1975) (Friendly, J.) (quoting Lopes v. Schroeder, 225 F. Supp. 292, 297 (E.D. Pa. 1963)).

189. 630 F.2d 876, 878 (2d Cir. 1980) (asserting that "deliberate torture perpetrated under color of official authority violates universally accepted norms of the international law of human rights," and gives rise to claims under the ATCA).

190. Id. at $880-85$. 
approach, ${ }^{191}$ repudiating earlier interpretations of the Act. ${ }^{192}$ The Central District of California, for instance, insisted on "ascertaining the content of the law of nations... not as it was in 1789 (the year the ATCA was enacted), but as it has evolved and exists among the nations of the world today." 193

Most recently, however, courts interpreting the ATCA have employed the principle of jus cogens, either explicitly or implicitly, as a way of more clearly ascertaining which torts violate the law of nations. Jus cogens refers to those rules of international law that are of fundamental importance to the international community. ${ }^{194}$ Courts have found violations of jus cogens to include the following acts: "genocide, racial discrimination, slavery, self determination of persons, murder/disappearances, torture, war crimes, and crimes against humanity." 195

Jus cogens norms are "related" to customary international law, but differ insofar as customary international law "rests on the consent of states," while "a state is bound by jus cogens norms even if it does not consent to their application." 196 The Restatement (Third) of Foreign Affairs acknowledges two categories of jus cogens norms: "the principles of the United Nations Charter prohibiting the use of force,"197 and fundamental human rights law prohibiting genocide, slavery, murder, torture, prolonged arbitrary detention, and racial discrimination. ${ }^{198}$

Courts have taken into account the concept of $j u s$ cogens in determining whether particular acts constitute violations of the law of nations in cases arising under the ATCA. For example, the Ninth Circuit ruled, "The right to

191. See, e.g., Doe v. Islamic Salvation Front, 993 F. Supp. 3, 7 (D.D.C. 1998) (citing Filartiga, $630 \mathrm{~F} .2 \mathrm{~d}$ at 880 , for the proposition that the "law of nations" is "known as international customary law'); Forti v. Suarez-Mason, 672 F. Supp. 1531, 1540 (N.D. Cal. 1987) (equating violations of the law of nations with "violations of current customary international law").

192. See, e.g., Filartiga, 630 F.2d at 884 (calling the dictum in Dreyfus "clearly out of tune with the current usage and practice of international law").

193. Doe v. Unocal Corp., 110 F. Supp. 2d 1294, 1304 (C.D. Cal. 2000) (citation omitted).

194. Jus cogens has been described as "among the most ambiguous and theoretically problematic of the doctrines of international law." Christopher A. Ford, Adjudicating Jus Cogens, 13 WIS. INT'L L.J. 145, 145 (1994). According to the Vienna Convention, jus cogens norms are "peremptory norm[s] of general international law" that are "accepted and recognized by the international community of States as a whole" and "from which no derogation is permitted." Vienna Convention on the Law of Treaties, Jan. 27, 1980, art. 53, 1155 U.N.T.S. 332, 344. A jus cogens norm "can be modified only by a subsequent norm of general international law having the same character." $I d$. Treaties conflicting with jus cogens norms at the time they are signed are "void." Id.; see also United States v. Matta-Ballesteros, 71 F.3d 754, 764 n.5 (9th Cir. 1995) ("Jus cogens norms, which are nonderogable and peremptory, enjoy the highest status within customary international law, are binding on all nations, and can not be preempted by treaty.").

195. Ladan Askari, Girls' Rights Under International Law: An Argument for Establishing Gender Equality as a Jus Cogens, 8 S. CAL. REV. L. \& WOMEN's STUD. 3,7 (1998).

196. Sampson v. Fed. Republic of Germany, 250 F.3d 1145, 1150 (7th Cir. 2001).

197. RESTATEMENT, supra note $24, \S 102 \mathrm{cmt}$. $\mathrm{k}$.

198. Id. $\$ 702 \mathrm{cmt}$. $\mathrm{n}$. 
be free from official torture is fundamental and universal, a right deserving of the highest status under international law, a norm of jus cogens." ${ }^{199}$ More recently, a California district court held, "It is well accepted that torture, murder, genocide and slavery all constitute violations of jus cogen $[s]$ norms." ${ }^{200}$ The Ninth Circuit, however, has so far declined to limit jurisdiction under the ATCA to jus cogens violations. ${ }^{201}$

If courts are not going to adhere to the actual meaning of the phrase "law of nations," we should hope their attempts at modernization remain as faithful as possible to it. The comparatively recent focus on jus cogens norms in interpreting the ATCA is encouraging because jus cogens is the closest modern analogue to the Framers' concept of the "law of nations," as discussed in Part II. ${ }^{202}$ Like the law of nations, "[j]us cogens norms, also referred to as peremptory norms, originated in natural law theories." 203 As with the law of nations, individual countries may not consent to violations of jus cogens norms. ${ }^{204}$ Instead of incorporating all aspects of customary and treaty-based international law, jus cogens only "restrains nations from transgressing upon those interests deemed basic and fundamental to the international order. $" 205$

Moreover, a jus cogens interpretation of the "law of nations" is consistent with much existing ATCA precedent. The criteria that many courts have used to identify violations of the law of nations are similar to the elements that courts consider in ascertaining jus cogens violations. ${ }^{206}$

199. Hileo v. Estate of Marcos, 25 F.3d 1467, 1475 (9th Cir. 1994) (quoting Siderman de Blake v. Republic of Argentina, 965 F.2d 699, 717 (9th Cir. 1992)); see also In re Estate of Marcos Human Rights Litig., 978 F.2d 493, 500 (9th Cir. 1992) ("We therefore conclude that the district court did not err in founding jurisdiction [under the ATCA] on a violation of the jus cogens norm prohibiting official torture.").

200. Doe v. Unocal Corp., 110 F. Supp. 2d 1294, 1304 (C.D. Cal. 2000).

201. See Alvarez-Machain v. United States, 266 F.3d 1045, 1050 (9th Cir. 2001).

202. But see William S. Dodge, Which Torts in Violation of the Law of Nations?, 24 HASTINGS INT'L \& COMP. L. REV. 351 (2001) (arguing that the phrase "law of nations" as used in the Alien Tort Claims Act should not be interpreted to refer only to jus cogens norms).

203. Ford, supra note 194, at 149 ("[T]he jus cogens formulation is a modern, secular reincarnation of natural law theories, embodying the idea of a higher moral order against which ordinary actions and legal rules must be judged."); Kha Q. Nguyen, Note, In Defense of the Child: A Jus Cogens Approach to the Capital Punishment of Juveniles in the United States, 28 GEO. WASH. J. INT'L L. \& ECON. 401, 417 (1995) (citations omitted).

204. Ford, supra note 194, at 152 ('No positivist state 'consent' can justify breaking a [jus cogens] norm, short of general agreement upon a rule displacing that norm.").

205. Nguyen, supra note 203, at 416.

206. See, e.g., Sarei v. Rio Tinto PLC, No. CV 00-11695-MMM(MANx), 2002 U.S. Dist. LEXIS 16235, at *37 (C.D. Cal. July 9, 2002) (holding that in evaluating ATCA claims, courts must consider whether plaintiffs "identify a specific, universal, and obligatory norm of international law"); In re World War II Japanese Forced Labor Litig., 164 F. Supp. 2d 1160, 1179 (N.D. Cal. 2001) ("Given the Ninth Circuit's comment ... that slavery constitutes a violation of jus cogens, this court is inclined to agree ... that forced labor violates the law of nations."); see also Mehinovic v. Vuckovic, 198 F. Supp. 2d 1322, 1344 (N.D. Ga. 2002) ("A jus cogens violation satisfies, but is not required, to meet [the ATCA's requirements]."'). 
The range of offenses recognized by courts as violating the "law of nations" is remarkably consistent with practices prohibited by jus cogens. ${ }^{207}$ Likewise, many claims that courts have not allowed to be brought under the ATCA were not violations of jus cogens. ${ }^{208}$

This is not to imply that jus cogens norms are perfectly clear. Although some authors appear to overstate the degree of inscrutability of such norms, ${ }^{209}$ even the International Law Commission has held that "there is not as yet any generally recognized criterion by which to identify a general rule of international law as having the character of jus cogens."210 Nonetheless, because it is closer to the true meaning of the phrase "law of nations," the concept of jus cogens is the best compromise approach to both the ATCA and the Offenses Clause. Under this method, Congress is empowered to enact federal statutes to "define and punish" violations of jus cogens norms, in addition to traditionally recognized offenses against the law of nations. Because, as discussed earlier, the range of jus cogens norms is fairly narrow, this reading of the Offenses Clause does not threaten federalism in the manner of the interpretations offered by Professor Stephens and the International Law Scholars.

\section{CONCLUSION}

Professor Stephens and the International Law Scholars offer a temptingly broad interpretation of the Offenses Clause that would allow it to serve as the constitutional authority for many laws struck down over the past decade by the Supreme Court. Their arguments are based on the fundamental misconception that the phrase "law of nations" as used in the Offenses Clause can be equated with either international law as a whole or

207. See Kadic v. Karadzic, 70 F.3d 232 (2d Cir. 1995) (holding that violations of the law of nations include genocide, war crimes, and official torture); Tel-Oren v. Libyan Arab Republic, 726 F.2d 774, 791 n.20 (D.C. Cir. 1984) (Edwards, J., concurring) ("On the basis of international covenants, agreements, and declarations, commentators have identified at least four acts that are now subject to uncquivocal international condemnation: torture, summary execution, genocide and slavery." (citations omitted)).

208. Areas not protected by jus cogens norms, and which have also been found to be not governed by the law of nations for purposes of bringing suit under the ATCA, include violations of free speech, Guinto v. Marcos, 654 F. Supp. 276, 280 (S.D. Cal, 1986), interference with property rights, De Sanchez v. Banco Central de Nicar., 770 F.2d 1385, 1397 (5th Cir. 1985), restrictions on free markets, Kruman v. Christie's Int'l PLC, 129 F. Supp. 2d 620, 627 (S.D.N.Y. 2001), and actions for libel, Akbar v. N.Y. Magazine Co., 490 F. Supp. 60, 63 (D.D.C. 1980).

209. Ford, supra note 194, at 165 ("Apart, however, from the comparatively uncontroversial genocide and slavery prohibitions - which still have their doctrinal critics nothing approaching a general consensus has developed regarding the substantive content of preemptory international law.").

210. Report of the International Law Commission, U.N. GAOR Int'l L. Comm'n, 18th Sess., Supp. No. 9, U.N. Doc. A/5509 (1963), reprinted in 58 AM. J. INT'L L. 241, 264 (1964). 
with customary international law. This Note has demonstrated that these are not the most accurate interpretations of the Clause.

I do not argue merely that the Framers interpreted the phrase "law of nations" differently than we do today. Instead, I maintain that they explicitly understood the concept to refer to a static body of principles; it was not something that could change with time. The law of nations, closely related to natural law, was binding on nations regardless of their consent, and its scope could not be altered through either treaty or custom. Thus, it makes little sense to insist, as modern courts have, on "ascertaining the content of the law of nations ... not as it was in 1789, but as it has evolved and exists among the nations of the world today."211

Moreover, having examined the writings of scholars who influenced the Framers, court rulings in the years around the Founding, and the Framers' brief discussion of the Offenses Clause, I have not discovered any evidence that the phrase "law of nations" was interpreted as governing the relationship between a country and its own citizens, except insofar as is necessary to protect a foreign nation or foreign nationals. The immutable principles comprising the law of nations were thought to govern only certain discrete areas including navigation, war, commerce, and diplomatic interactions with other nations. It is only with regard to these subjects that Congress may legislate under the Offenses Clause. Such an interpretation is consistent with the results reached in prior cases under the Offenses Clause.

If courts are reluctant to adopt this reasoning, however, a legitimate compromise would be to employ jus cogens as a modern analogue to the law of nations. Jus cogens, like the law of nations, is nonderogable and binding on nations irrespective of consent. Neither treaties nor customary norms can change the substantive content of a jus cogens norm. Moreover, jus cogens norms pose few restrictions on a nation's domestic affairs, thus alleviating the federalism concerns to which an expansive reading of the Offenses Clause gives rise. Whether one accepts the strong form of my argument, or settles for the jus cogens compromise, it is clear that a conception of the phrase "law of nations" different than that advanced by Professor Stephens is necessary not only to provide a more accurate interpretation of the Constitution, but also to protect the delicate balance of federalism carefully erected by the Framers more than two hundred years ago.

211. Doe v. Unocal Corp., 110 F. Supp. 2d 1294, 1304 (C.D. Cal. 2000). 
***

Imaged with the Permission of Yale Law Journal 